\title{
PENGARUH PENGELUARAN PEMERINTAH TERHADAP PERTUMBUHAN EKONOMI DI PROVINSI BENGKULU
}

\author{
Merri Anitasari \\ Fakultas Ekonomi dan Bisnis Universitas Bengkulu \\ Ahmad Soleh \\ Fakultas Ekonomi Universitas Dehasen Bengkulu
}

\begin{abstract}
ABSTRAK
Merri Anitasari, Ahmad Soleh; Pengaruh Pengeluaran Pemerintah Terhadap Pertumbuhan Ekonomi Di Provinsi Bengkulu. Tujuan dari penelitian ini adalah untuk menganalisis pengaruh dari pengeluaran pemerintah terhadap pertumbuhan ekonomi di provinsi Bengkulu dengan menggunakan data sekunder periode pengamatan tahun 2001-2012 yang diperoleh dari Badan Pusat Statistik. Hasil analisis dengan menggunakan SPSS 16 menunjukkan bahwa pengeluaran pemerintah berpengaruh positif dan signifikan terhadap pertumbuhan ekonomi di provinsi Bengkulu. Jika pemerintah menaikkan pengeluaran pemerintah sebesar 1 miliar rupiah, maka akan dapat meningkatkan pertumbuhan ekonomi sebesar 1,17 \% per tahun. Sedangkan pengaruh pengeluaran pemerintah terhadap pertumbuhan ekonomi di daerah kabupaten/kota menunjukkan bahwa dari jumlah 10 kabupaten/kota di Provinsi Bengkulu, kabupaten Rejang Lebong dan kota Bengkulu yang memiliki hasil bahwa pengeluaran pemerintah berpengaruh positif dan signifikan terhadap pertumbuhan ekonomi di daerahnya. Kabupaten Bengkulu Utara memiliki pengaruh yang negatif sedangkan 7 kabupaten lainnya memiliki hasil yang positif namun tidak signifikan. Sebagian besar kabupaten di Provinsi Bengkulu dikategorikan sebagai daerah yang baru membangun yang merupakan hasil pemekaran pasca pemberlakuan otonomi daerah. Sehingga dalam jangka pendek pengeluaran pemerintah dianggap belum mampu menstimulus kegiatan sektor-sektor perekonomian serta memacu pertumbuhan ekonomi di daerah tersebut.
\end{abstract}

\section{ABSTRACT}

Merri Anitasari, Ahmad Soleh; Impact of Government Spending on Economic Growth In Bengkulu Province. The purpose of this study was to analyze the impact of government spending on economic growth in the province of Bengkulu using secondary data observation period 20012012 year were obtained from the Central Bureau of Statistics. Results of analysis using SPSS 16 shows that government spending and significant positive effect on economic growth in the province of Bengkulu. If the government raised government spending by 1 billion dollars, it will be able to boost economic growth by $1.17 \%$ per year. While the effect of government spending on economic growth in the district/city showed that of a total of 10 districts cities in Bengkulu province, Rejang Lebong district and Bengkulu City which has the result that government spending and significant positive effect on economic growth in the region. North Bengkulu has a negative effect, while seven other districts have a positive outcome, but not significantly. Most districts in the province of Bengkulu categorized as new building is the result of the division after the implementation of regional autonomy. So in the short-term government spending is considered not able to stimulate activity sectors of the economy and spur economic growth in the area.

\section{Key Word: Government Spending, Economic Growth, Bengkulu Province}

\section{PENDAHULUAN}

Sebagai negara berkembang, pemerintah memiliki peran penting dalam mempercepat pembangunan ekonomi. Berbagai kebijakan dilakukan dalam pencapaian tujuan pembangunan ekonomi. Kebijakan fiskal merupakan kebijakan ekonomi yang dilakukan oleh pemerintah terhadap penerimaan dan pengeluaran untuk mencapai tujuan seperti pertumbuhan ekonomi 
dan stabilitas perekonomian secara umum. Perubahan tingkat dan komposisi anggaran pemerintah baik pajak maupun pengeluaran pemerintah, dapat mempengaruhi variabelvariabel permintaan agregat dan tingkat aktivitas ekonomi, pola persebaran sumber daya, dan distribusi pendapatan.

Pengeluaran Pemerintah merupakan bagian dari kebijakan fiskal yaitu suatu tindakan pemerintah untuk mengatur jalannya perekonomian dengan cara menentukan besarnya penerimaan dan pengeluaran pemerintah setiap tahunnya, yang tercermin dalam dokumen Anggaran Pendapatan Belanja Negara (APBN) untuk nasional dan Anggaran Pendapatan Belanja Daerah (APBD) untuk daerah atau regional. Tujuan dari kebijakan fiskal ini adalah dalam rangka menstabilkan harga, tingkat output, maupun kesempatan kerja dan memacu atau mendorong pertumbuhan ekonomi.

Penyelenggaraan otonomi daerah yang dimulai pada Januari 2001 bagi setiap daerah tingkat provinsi maupun kabupaten memuat dua aspek penting, yaitu pendelegasian kewenangan pemerintah pusat kepada pemerintah daerah dalam penyelenggaraan pemerintah maupun tugas pembangunan dan pengelolaan sumber-sumber ekonomi yang meliputi penggalian sumber-sumber penerimaan dan pengalokasian pengeluaran sesuai dengan kebutuhan dan prioritas daerah masing-masing. Dari aspek ekonomi, kebijakan otonomi daerah yang bertujuan untuk pemberdayaan kapasitas daerah akan memberikan kesempatan bagi daerah untuk mengembangkan dan meningkatkan perekonomiannya. Peningkatan pertumbuhan perekonomian daerah akan membawa pengaruh yang signifikan terhadap peningkatan kesejahteraan rakyat di daerah. Melalui kewenangan yang dimiliki untuk mengatur dan mengurus kepentingan masyarakat, daerah akan berupaya untuk meningkatkan perekonomian sesuai dengan kondisi, kebutuhan dan kemampuan. Kewenangan daerah melalui otonomi daerah diharapkan dapat memberikan pelayanan maksimal kepada para pelaku ekonomi di daerah baik lokal, regional, nasional maupun global.

Pengeluaran pemerintah daerah (provinsi maupun kabupaten/kota) yang tercermin dalam APBD dibagi menjadi dua kelompok utama yaitu pengeluaran rutin atau belanja aparatur daerah dan pengeluaran pembangunan atau belanja pelayanan publik. Dari dua jenis pengeluaran tersebut, pengeluaran rutin atau belanja aparatur daerah merupakan jenis pengeluaran yang dominan dalam pengeluaran pembangunan di sebagian besar di daerah baik di provinsi Bengkulu maupun di sebagian besar daerah di Indonesia. Pengeluaran rutin atau belanja aparatur daerah meliputi belanja pegawai, barang, pemeliharaan, perjalanan dinas, pinjaman beserta bunga dan subsidi. Semua jenis pengeluaran tersebut sifatnya merupakan pengeluaran konsumsi. Sedangkan pengeluaran pembangunan atau belanja pelayanan publik terbagi menurut sektor-sektor pembangunan yang lebih bersifat sebagai akumulasi stok kapital. Kondisi tersebut di atas diharapkan dapat menjadi perhatian bagi pemerintah untuk lebih meningkatkan alokasi pengeluaran pembangunan agar mampu menstimulus pertumbuhan ekonomi.

\section{TINJAUAN LITERATUR}

\section{Pertumbuhan Ekonomi}

Menurut Todaro dan Smith (2006) pertumbuhan ekonomi merupakan suatu proses peningkatan kapasitas produktif dalam suatu perekonomian secara terus menerus atau berkesinambungan sepanjang waktu sehingga menghasilkan tingkat pendapatan dan output nasional yang semakin lama semakin besar. Tiga komponen pertumbuhan ekonomi yang penting bagi setiap masyarakat adalah (1) Akumulasi modal, termasuk di dalamnya semua investasi baru dalam bentuk tanah, peralatan fisik dan sumber daya manusia melalui perbaikan di bidang kesehatan, pendidikan dan keterampilan kerja, (2) Pertumbuhan jumlah penduduk yang pada akhirnya menyebabkan petumbuhan angkatan kerja, (3) Kemajuan teknologi yang secara luas diartikan sebagai cara baru dalam menyelesaikan pekerjaan.

Pertumbuhan ekonomi yang tinggi dan prosesnya yang berkelanjutan merupakan kondisi utama bagi kelangsungan pembangunan ekonomi (Tambunan, 2001). Pertumbuhan 
ekonomi menunjukkan sejauh mana aktivitas perekonomian akan menghasilkan tambahan pendapatan masyarakat pada suatu periode tertentu. Dengan kata lain, perekonomian dikatakan mengalami pertumbuhan bila pendapatan riil masyarakat pada tahun tertentu lebih besar dari pada pendapatan riil masyarakat pada tahun sebelumnya.

Pertumbuhan ekonomi merupakan faktor terpenting dalam pembangunan. Keberhasilan pembangunan suatu negara/wilayah diukur berdasarkan tinggi rendahnya tingkat pertumbuhan ekonomi yang dicapai. Pengukuran pertumbuhan ekonomi secara konvensional biasanya dengan menghitung peningkatan persentase dari Produk Domestik Bruto (PDB) untuk nasional dan Produk Domestik Regional Bruto (PDRB) untuk provinsi maupun kabupaten/kota. PDRB merupakan jumlah nilai tambah yang dihasilkan oleh seluruh unit usaha dalam suatu wilayah tertentu atau merupakan jumlah nilai barang dan jasa akhir yang dihasilkan oleh seluruh unit ekonomi selama periode tertentu. Oleh karena itu, pertumbuhan ekonomi suatu wilayah dapat diperoleh melalui tingkat pertumbuhan nilai PDRB Atas Dasar Harga Konstan (ADHK).

\section{Teori Pertumbuhan Ekonomi}

Teori pertumbuhan ekonomi menjelaskan faktor-faktor yang menentukan pertumbuhan ekonomi serta bagaimana keterkaitan antara faktor-faktor tersebut sehingga terjadi proses pertumbuhan. Terdapat banyak teori-teori pertumbuhan ekonomi tetapi tidak satu teoripun yang komprehensif yang dapat menjadi standar yang baku, karena masing-masing teori memiliki kekhasan sendiri-sendiri sesuai dengan latar belakang teori tersebut.

Dalam kajian ini akan dipaparkan teori pertumbuhan ekonomi yang dianggap cukup untuk menerangkan sumber-sumber pertumbuhan ekonomi yaitu teori Solow-Swan. Teori pertumbuhan ini dikembangkan oleh Robert Solow (Massachussets Institute of Technology) dan Trevor Swan (The Australian National University). Menurut teori ini, pertumbuhan ekonomi tergantung pada pertambahan penyediaan faktor-faktor produksi (penduduk, tenaga kerja, dan akumulasi modal) dan tingkat kemajuan teknologi. Pandangan ini didasarkan analisis klasik, bahwa perekonomian akan tetap mengalami tingkat pengerjaan penuh (full employment) dan kapasitas peralatan modal akan tetap sepenuhnya digunakan sepanjang waktu.

Selanjutnya menurut teori ini, rasio modal-output (capital-output ratio $=\mathrm{COR}$ ) dapat berubah dan bersifat dinamis. Untuk menciptakan sejumlah output tertentu, bisa digunakan jumlah modal yang berbeda-beda dengan bantuan tenaga kerja yang jumlahnya berbeda-beda sesuai dengan yang dibutuhkan. Jika lebih banyak modal yang digunakan maka tenaga kerja yang dibutuhkan lebih sedikit, sebaliknya jika modal yang digunakan lebih sedikit maka lebih banyak tenaga kerja yang digunakan. Dengan adanya fleksibilitas ini suatu perekonomian mempunyai kebebasan yang tak terbatas dalam menentukan kombinasi modal dan tenaga kerja yang akan digunakan untuk menghasilkan tingkat output tertentu.

Dengan berdasarkan prinsip-prinsip dalam teori Solow-Swan, E.F. Denison melakukan analisis perhitungan atas sumber-sumber pertumbuhan output Amerika Serikat pada tahun 1909 sampai dengan 1957. Hasil analisis menunjukkan bahwa pertumbuhan ekonomi selain ditentukan oleh faktor-faktor produksi juga dipengaruhi oleh kemajuan teknologi misalnya pendidikan, pengalaman, dan kemajuan pengetahuan (Wijono, 2005).

Menurut pandangan ekonom klasik, Adam Smith, David Ricardo, Thomas Robert Malthus dan John Straurt Mill, maupun ekonom neo klasik, Robert Solow dan Trevor Swan, mengemukakan bahwa pada dasarnya ada empat faktor yang mempengaruhi pertumbuhan ekonomi yaitu (1) jumlah penduduk, (2) jumlah stok barang modal, (3) luas tanah dan kekayaan alam, dan (4) tingkat teknologi yang digunakan.

\section{Pengeluaran Pemerintah}

Dalam kebijakan fiskal dikenal ada beberapa kebijakan anggaran yaitu anggaran berimbang, anggaran surplus dan anggaran defisit. Dalam pengertian umum, anggaran berimbang yaitu suatu kondisi dimana penerimaan sama dengan pengeluaran. Anggaran 
surplus yaitu pengeluaran lebih kecil dari penerimaan. Sedangkan anggaran defisit yaitu anggaran pengeluaran lebih besar dari penerimaan. Anggaran surplus digunakan jika pemerintah ingin mengatasi masalah inflasi. Sedangkan anggaran defisit digunakan jika pemerintah ingin mengatasi masalah pengangguran dan peningkatan pertumbuhan ekonomi. Jika pemerintah merencanakan peningkatan pertumbuhan ekonomi untuk mengurangi angka pengangguran maka pemerintah dapat meningkatkan pengeluarannya. Pengeluaran pemerintah terdiri dari pengeluaran rutin atau belanja aparatur daerah dan pengeluaran pembangunan atau belanja pelayanan publik

\section{Teori Pengeluaran Pemerintah}

Pengeluaran Pemerintah Versi Keynes, pengeluaran pemerintah merupakan salah satu unsur permintaan agregat. Konsep perhitungan pendapatan nasional dengan pendekatan pengeluaran bahwa $Y=C+I+G+X-M$. Formula ini dikenal sebagai identitas pendapatan nasional. Variabel $Y$ melambangkan pendapatan nasional sekaligus mencerminkan penawaran agregat. Sedangkan variabel-variabel di ruas kanan disebut permintaan agregat. Variabel G melambangkan pengeluaran pemerintah. Dengan membandingkan nilai G terhadap Y serta mengamati dari waktu ke waktu dapat diketahui seberapa besar kontribusi pengeluaran pemerintah dalam pembentukan pendapatan nasional (Dumairy, 1996)

Teori pembangunan dan pengeluaran pemerintah dikembangkan oleh Rostow dan Musgrave yang menghubungkan pengeluaran pemerintah dengan tahap-tahap pembangunan ekonomi yang dibedakan antara tahap awal, tahap menengah dan tahap lanjut. (1) Tahap awal, pada tahap awal perkembangan ekonomi persentase investasi besar, sebab pemerintah harus menyediakan prasarana, seperti pendidikan, kesehatan, prasarana transportasi dan sebagainya. (2) Tahap menengah, investasi pemerintah tetap diperlukan untuk meningkatkan pertumbuhan ekonomi agar dapat tinggal landas, namun peranan investasi swasta sudah semakin membesar. (3) Tahap lanjut, pembangunan ekonomi dan aktivitas pemerintah beralih dari penyediaan prasarana ke pengeluaran-pengeluaran untuk aktivitas sosial seperti program kesejahteraan hari tua dan program pelayanan kesehatan masyarakat (Mangkoesoebroto, 2001).

\section{METODE PENELITIAN}

Penelitian ini menggunakan pendekatan kuantitatif dan analisis ekonometrik. Pengolahan data dilakukan dengan menggunakan SPSS 16. Penelitian ini bermaksud menjelaskan pengaruh pengeluaran pemerintah terhadap pertumbuhan ekonomi provinsi Bengkulu. Data yang digunakan berupa data sekunder time series dari tahun 2001-2012 yang diperoleh dari Badan Pusat Statistik Nasional dan Daerah.

\section{KERANGKA ANALISIS}

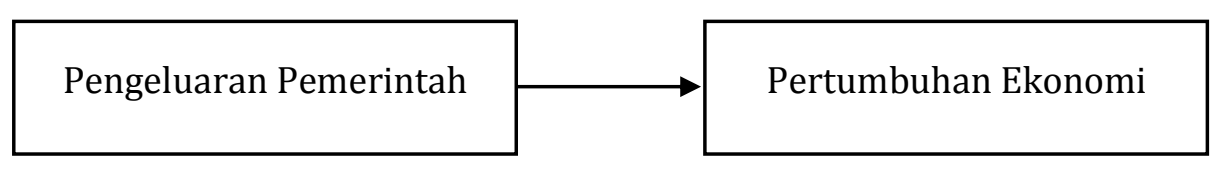

Gambar 1. Kerangka Analisis

\section{HASIL PENELITIAN DAN PEMBAHASAN}

\section{Kondisi Geografis dan Demografis Provinsi Bengkulu}

Secara geografis Provinsi Bengkulu terletak pada 101' 01" dan 103' 41" Bujur Timur serta $20^{\prime}$ 16" dan 3' 31" Lintang Selatan dengan ketinggian dari permukaan laut 0-20 m 
(Bengkulu) sampai dengan 627-733 (Curup). Provinsi ini terletak di Pantai Barat Pulau Sumatera, membujur dari Utara ke Selatan, di antara Bukit Barisan di sebelah Timur dan Samudera Indonesia di sebelah Barat dengan luas wilayah lebih kurang $21.089,38 \mathrm{~km}^{2}$ atau 2.108.938 ha.

Pada tahun 2012, penduduk provinsi Bengkulu tercatat sebanyak 1,77 juta jiwa. Dengan demikian laju pertumbuhan penduduk provinsi Bengkulu di atas laju pertumbuhan penduduk Indonesia yaitu 1,42 \% sedangkan laju pertumbuhan penduduk Indonesia sebesar 1,32\%. Sementara itu, sex ratio sebesar 104 yang menunjukkan bahwa penduduk laki-laki lebih banyak $4 \%$ dibandingkan dengan penduduk perempuan. Sebaran penduduk menurut kabupaten menunjukkan bahwa jumlah penduduk provinsi ini tidak merata tersebar dalam 10 kabupaten/kota dan masih terkonsentrasi di ibukota provinsi yaitu kota Bengkulu. Kota Bengkulu memiliki kepadatan sebesar 208 jiwa per $\mathrm{km}^{2}$ sedangkan kabupaten tersepi adalah Mukomuko dengan kepadatan hanya sebesar 40 jiwa per $\mathrm{km}^{2}$.

Berdasarkan umur, penduduk provinsi Bengkulu didominasi oleh penduduk usia produktif (20-55 tahun). Penduduk usia produktif ini tercatat sebanyak $57 \%$ sedangkan penduduk usia muda (0-19 tahun) sebesar 39,2\% dan sisanya yang merupakan penduduk usia tua mencapai 3,7 \%. Melihat komposisi ini, terdapat potensi tenaga kerja yang besar pada masa yang akan datang.

\section{Pertumbuhan Ekonomi Kabupaten/Kota dan Provinsi Bengkulu}

Pertumbuhan ekonomi yang tinggi merupakan salah satu sasaran yang akan dicapai dalam pelaksanaan pembangunan di suatu daerah. Hal ini dapat diukur berdasarkan kenaikan Produk Domestik Regional Bruto (PDRB) dari tahun ke tahun. Dengan kata lain PDRB merupakan tolok ukur perkembangan ekonomi secara regional yang dapat digunakan sebagai dasar perencanaan pembangunan nasional. Pertumbuhan ekonomi regional yang dicerminkan oleh PDRB sangat dipengaruhi oleh faktor-faktor yang turut memberi andil dalam pertumbuhan produksi dari masing-masing sektor. Perkembangan PDRB baik berdasarkan atas dasar harga konstan maupun atas dasar harga berlaku dari tahun ke tahun dapat mencerminkan laju pertumbuhan ekonomi di suatu daerah, pertumbuhan ini tentunya akan dapat menggambarkan kemajuan pembangunan ekonomi di daerah tersebut selama kurun waktu tertentu.

Selama periode pengamatan, trend pertumbuhan ekonomi provinsi Bengkulu cenderung mengalami kenaikan. Penurunan pertumbuhan ekonomi pernah terjadi pada tahun 2008 hingga tahun 2009, pertumbuhan ekonomi mengalami penurunan dari 6,46\% pada tahun 2007 menjadi 5,75\% pada tahun 2008 atau mengalami penurunan sebesar 0,71\% dari tahun sebelumnya. Pada tahun 2009, pertumbuhan ekonomi masih cenderung menurun yaitu sebesar $5,62 \%$ atau kembali mengalami penurunan sebesar $0,13 \%$ dari tahun sebelumnya. Fenomena tersebut lebih disebabkan oleh krisis moneter yang terjadi secara nasional. Dengan semakin membaiknya kinerja perekonomian, mulai tahun 2010 hingga tahun 2012, pertumbuhan ekonomi provinsi Bengkulu cenderung mengalami peningkatan.

Tidak jauh berbeda dengan pola pertumbuhan ekonomi provinsi Bengkulu, pertumbuhan ekonomi antar kabupaten/kota mengalami fluktuasi dari tahun ke tahun. Namun secara umum, trend pertumbuhan ekonomi antar kabupaten/kota cenderung mengalami kenaikan. Adanya krisis moneter pada tahun 2008 juga memberikan imbas pada penurunan pertumbuhan ekonomi di sebagian besar kabupaten/kota di provinsi Bengkulu. Secara ratarata, pertumbuhan ekonomi kabupaten/kota serta jika dibanding dengan provinsi Bengkulu dapat dilihat pada gambar 2 . 


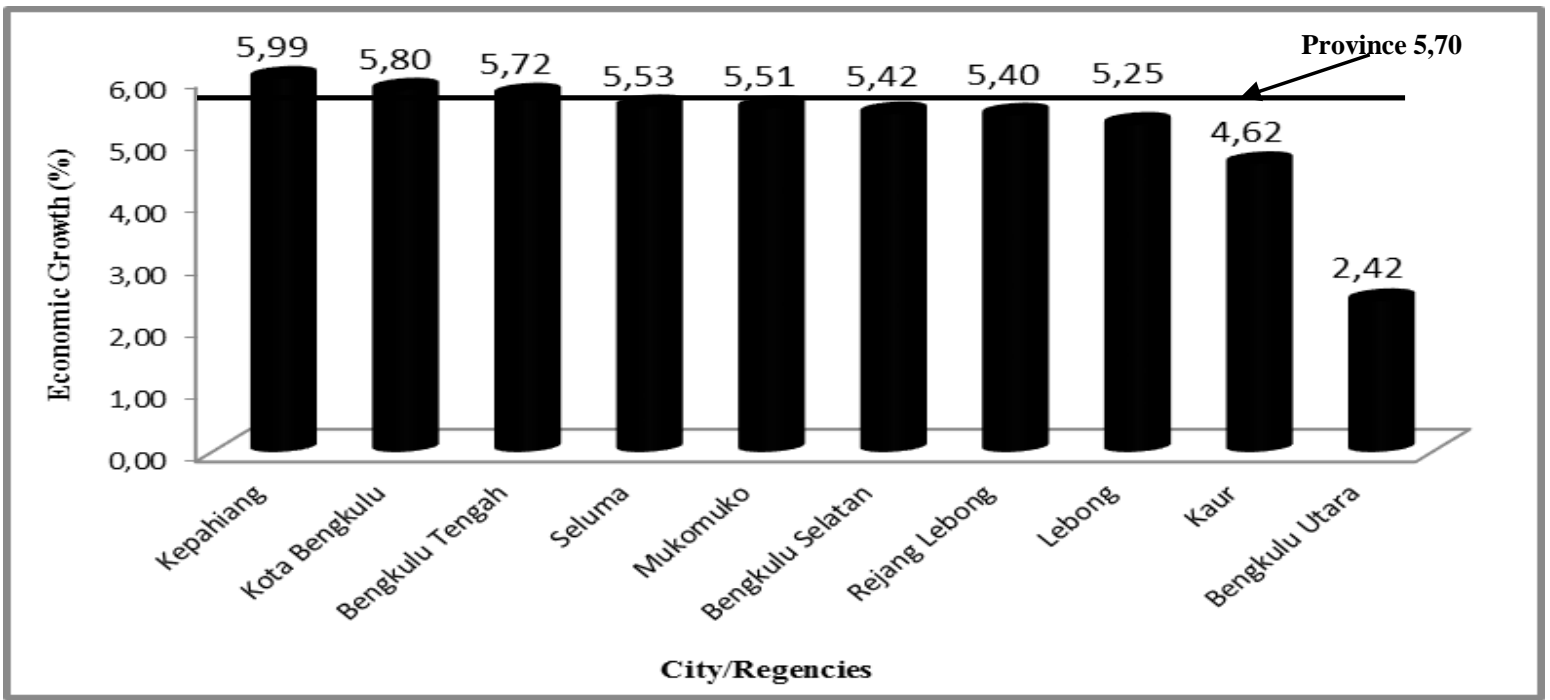

Gambar 2. Rata-Rata Pertumbuhan Ekonomi Kabupaten/Kota dan Provinsi Bengkulu Tahun 2001-2012

Berdasar gambar 2 di atas, menunjukkan bahwa sebagian besar kabupaten di provinsi Bengkulu memiliki rata-rata pertumbuhan ekonomi yang lebih rendah jika dibanding dengan rata-rata pertumbuhan ekonomi provinsi yaitu sebesar 5,70 \% per tahun. Hanya terdapat tiga kabupaten yang memiliki rata-rata pertumbuhan ekonomi di atas rata-rata pertumbuhan ekonomi provinsi yaitu kabupaten Kepahiang (5,99 \% per tahun), Kota Bengkulu (5,80 \% per tahun) dan Kabupaten Bengkulu Tengah (5,72 \% per tahun). Kabupaten Bengkulu Utara merupakan daerah dengan rata-rata pertumbuhan ekonomi paling rendah jika dibanding dengan daerah lainnya. Rendahnya rata-rata pertumbuhan ekonomi di kabupaten ini disebabkan oleh rendahnya pertumbuhan ekonomi yang terjadi pada tahun 2008 hingga mencapai $-28.75 \%$. Kondisi ini menyebabkan secara akumulasi rata-rata pertumbuhan ekonomi menjadi sangat kecil.

\section{Pengeluaran Pemerintah Kabupaten/Kota dan Provinsi Bengkulu}

Salah satu fungsi utama anggaran pemerintah daerah adalah sebagai alat kebijakan fiskal yang digunakan untuk menstabilkan ekonomi dan mendorong laju pertumbuhan ekonomi. Bagi pemerintah pusat, realisasi kegiatan pemerintah tercermin dalam Anggaran Pendapatan dan Belanja Negara (APBN) sedangkan bagi pemerintah daerah tercermin dalam Anggaran Penerimaan dan Belanja Daerah (APBD) yaitu pada bagian pengeluaran (belanja) yang terdiri dari pengeluaran rutin atau belanja aparatur daerah dan pengeluaran pembangunan atau belanja pelayanan publik.

Pengeluaran pemerintah biasanya mencerminkan kebijakan pemerintah dalam penentuan anggarannya. Pengeluaran pemerintah terus berkembang seiring dengan meningkatnya aktifitas pemerintah dalam perekonomian yang antara lain disebabkan oleh adanya perubahan-perubahan dalam perekonomian seperti pertumbuhan ekonomi, perubahan demografi, dan perubahan kegiatan sektor swasta. Dengan demikian pemerintah harus dapat memainkan perannya dalam mengatur tingkat alokasi penggunaan sumber-sumber daya serta distribusi pendapatan diantara konsumen sehingga dapat mempertahankan tingkat kesempatan kerja yang tinggi, tingkat stabilitas harga serta laju pertumbuhan ekonomi yang tinggi.

Perkembangan jumlah penduduk kabupaten/kota di provinsi Bengkulu menuntut adanya pengeluaran pembiayaan sebagai upaya peningkatan kesejahteraan rakyat. Dengan adanya peningkatan pengeluaran pemerintah diharapkan kemampuan dalam menciptakan sarana dan prasarana pembangunan yang meningkat dan pada akhirnya akan mendorong 
aggregate demand juga akan meningkat, sehingga dapat merangsang kegiatan produksi daerah yang selanjutnya dapat meningkatkan laju pertumbuhan ekonomi.

Pengeluaran pemerintah di tingkat kabupaten/kota maupun provinsi Bengkulu cenderung mengalami peningkatan. Pengeluaran rutin atau belanja aparatur daerah merupakan pengeluaran yang dominan atau memiliki persentase yang lebih tinggi dari pengeluaran pembangunan atau belanja pelayanan publik. Rata-rata pengeluaran pemerintah kabupaten/kota dan provinsi Bengkulu dapat dilihat pada gambar 3.

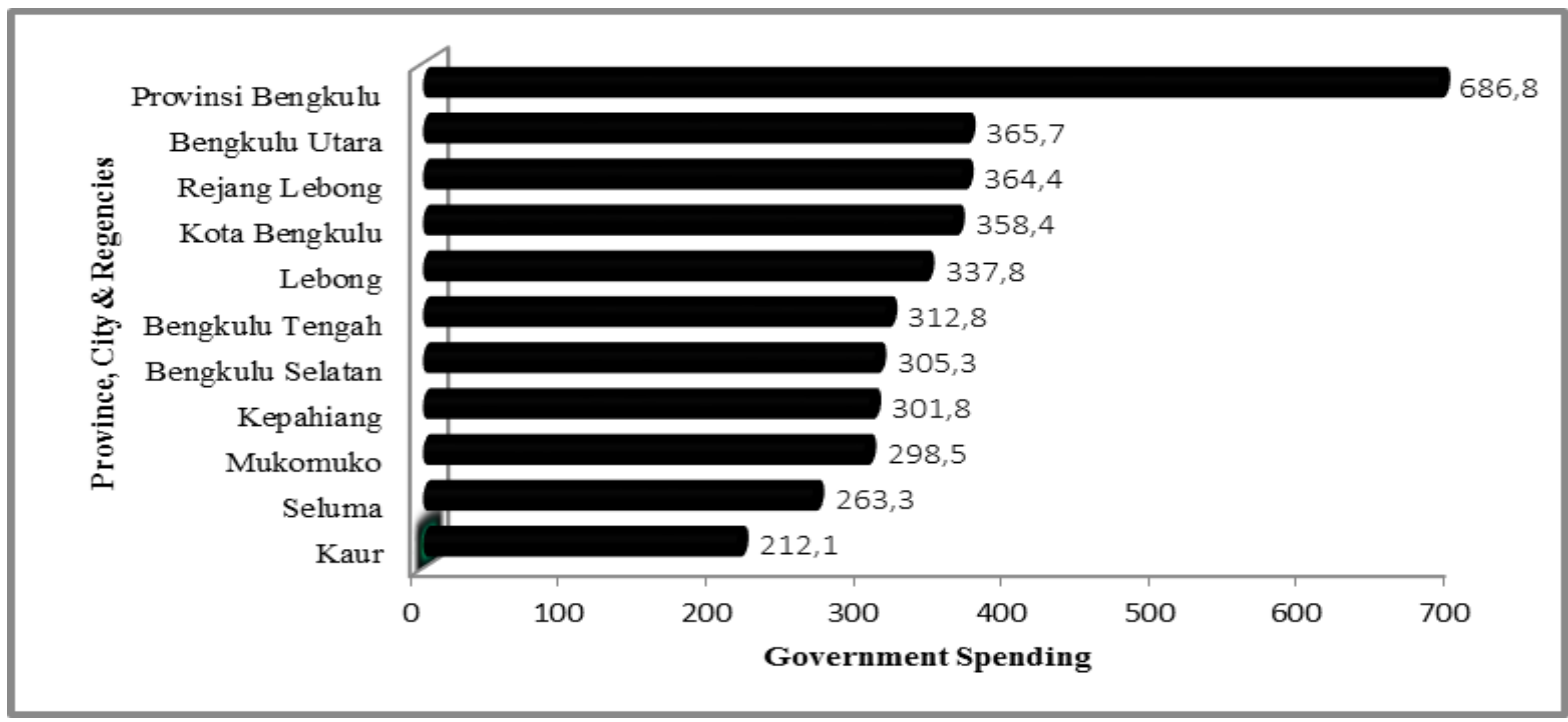

Gambar 3. Rata-Rata Pengeluaran Pemerintah Kabupaten/Kota dan Provinsi Bengkulu Tahun 2001-2012

Berdasar gambar 3. diketahui bahwa rata-rata pengeluaran pemerintah provinsi Bengkulu mencapai 686,6 miliar rupiah per tahun, nilai ini hampir dua kali lipat dari rata-rata kabupaten/kota. Kabupaten/Kota dengan rata-rata pengeluaran pemerintah yang tinggi masing-masing adalah Kabupaten Bengkulu Utara (365,7 Miliar Rupiah), Rejang lebong (364,4 Miliar Rupiah) dan Kota Bengkulu (358,4 Miliar Rupiah). Sedangkan daerah dengan rata-rata pengeluaran pemerintah terendah masing-masing adalah Kabupaten Kaur (212,1 Miliar Rupiah), Kabupaten Seluma (263,3 Miliar Rupiah) dan Kabupaten Mukomuko (298,5 Miliar Rupiah). Perbedaan dan perkembangan pengeluaran pemerintah seiring dengan meningkatnya aktifitas pemerintah dalam perekonomian yang antara lain disebabkan oleh adanya perubahanperubahan dalam perekonomian seperti pertumbuhan ekonomi, perubahan demografi, dan perubahan kegiatan sektor swasta.

\section{Pengaruh Pengeluaran Pemerintah Terhadap Pertumbuhan Ekonomi Provinsi Bengkulu}

Dalam menjelaskan pengaruh pengeluaran pemerintah terhadap pertumbuhan ekonomi di provinsi Bengkulu digunakan alat analisis regresi linier sederhana dengan menggunakan SPSS 16. Dari hasil perhitungan diketahui bahwa pengeluaran pemerintah memiliki pengaruh terhadap pertumbuhan ekonomi provinsi Bengkulu. Adapun persamaan regresi yang terbentuk adalah $\mathrm{Y}=4,893+1,174 \mathrm{x}$. Berdasar persamaan tersebut dapat dijelaskan bahwa koefisien regresi 1,174 dengan tanda positif. Hal ini menunjukkan bila semakin tinggi pengeluaran pemerintah akan dapat meningkatkan pertumbuhan ekonomi di provinsi Bengkulu.

Dari hasil pengolahan data diperoleh nilai korelasi sebesar 0,717. Hal ini menunjukkan hubungan antara pengeluaran pemerintah dan pertumbuhan ekonomi provinsi Bengkulu adalah kuat. Selanjutnya uji determinasi digunakan untuk mengetahui seberapa besar kemampuan variabel independen dalam menjelaskan secara komprehensif terhadap variabel dependen. Hasil dari oleh data diperoleh nilai $\mathrm{R}^{2}$ sebesar 0,514 artinya bahwa variabel 
pengeluaran pemerintah memiliki pengaruh atau kontribusi sebesar 51,4 \% terhadap pertumbuhan ekonomi dan 48,6\% dipengaruhi oleh faktor lain.

Uji $t$ digunakan untuk membuktikan pengaruh pengeluaran pemerintah terhadap pertumbuhan ekonomi secara individual (parsial). Pengujian ini dibuktikan dengan membandingkan nilai probabilitas dengan taraf signifikansi 0,05 . Jika nilai probability lebih kecil dari 0,05 maka signifikan atau memiliki pengaruh dan sebaliknya jika nilai probability lebih besar dari 0,05 maka dapat disimpulkan tidak signifikan pengaruh dari variabel terikatnya. Dari hasil pengolahan data diperoleh nilai t-statistik untuk variabel pengeluaran pemerintah sebesar 3,254 dan nilai probabilitity sebesar 0,009. Maka dapat disimpulkan bahwa variabel pengeluaran pemerintah berpengaruh signifikan terhadap pertumbuhan ekonomi provinsi Bengkulu.

\section{Pengaruh Pengeluaran Pemerintah Terhadap Pertumbuhan Ekonomi Kabupaten/Kota di Provinsi Bengkulu}

\section{1) Kota Bengkulu}

Dari hasil pengolahan data diketahui bahwa pengeluaran pemerintah memiliki pengaruh terhadap pertumbuhan ekonomi kota Bengkulu. Adapun persamaan regresi yang terbentuk adalah $\mathrm{Y}=4,734+2,968 \mathrm{x}$. Berdasar persamaan tersebut dapat dijelaskan bahwa koefisien regresi 2,968 dengan tanda positif. Hal ini menunjukkan bila semakin tinggi pengeluaran pemerintah akan dapat meningkatkan pertumbuhan ekonomi di kota Bengkulu. Hubungan antara pengeluaran pemerintah dan pertumbuhan ekonomi kota Bengkulu adalah kuat, hal ini ditunjukkan dengan nilai korelasi sebesar 0,711. Nilai $\mathrm{R}^{2}$ sebesar 0,505 artinya bahwa variabel pengeluaran pemerintah memiliki pengaruh atau kontribusi sebesar 50,5\% terhadap pertumbuhan ekonomi dan 49,5\% dipengaruhi oleh faktor lain. Nilai t-statistik untuk variabel pengeluaran pemerintah sebesar 3,194 dan nilai probabilitity sebesar 0,010. Maka dapat disimpulkan bahwa variabel pengeluaran pemerintah berpengaruh signifikan terhadap pertumbuhan ekonomi di Kota Bengkulu.

\section{2) Kabupaten Rejang Lebong}

Pengeluaran pemerintah memiliki pengaruh terhadap pertumbuhan ekonomi di kabupaten Rejang Lebong. Dari hasil pengolahan data, persamaan regresi yang terbentuk adalah $\mathrm{Y}=$ $3,625+4,860 x$. Berdasar persamaan tersebut dapat dijelaskan bahwa koefisien regresi 4,860 dengan tanda positif. Hal ini menunjukkan bila semakin tinggi pengeluaran pemerintah akan dapat meningkatkan pertumbuhan ekonomi di kabupaten Rejang Lebong. Hubungan antara pengeluaran pemerintah dan pertumbuhan ekonomi cukup berarti, hal ini ditunjukkan dengan nilai korelasi sebesar 0,621. Nilai $\mathrm{R}^{2}$ sebesar 0,386 artinya bahwa variabel pengeluaran pemerintah memiliki pengaruh atau kontribusi sebesar 38,6\% terhadap pertumbuhan ekonomi dan 61,4 \% dipengaruhi oleh faktor lain. Nilai t-statistik untuk variabel pengeluaran pemerintah sebesar 2,507 dan nilai probabilitity sebesar 0,031. Maka dapat disimpulkan bahwa variabel pengeluaran pemerintah berpengaruh signifikan terhadap pertumbuhan ekonomi di kabupaten Rejang Lebong.

\section{3) Kabupaten Bengkulu Selatan}

Dari hasil pengolahan data diketahui bahwa pengeluaran pemerintah memiliki pengaruh positif terhadap pertumbuhan ekonomi dengan persamaan regresi yang terbentuk adalah $Y$ $=4,648+2,523 \mathrm{x}$. Namun hubungan antara pengeluaran pemerintah dan pertumbuhan ekonomi cukup berarti, hal ini ditunjukkan dengan nilai korelasi sebesar 0,456 . Nilai $\mathrm{R}^{2}$ sebesar 0,208 artinya bahwa variabel pengeluaran pemerintah memiliki pengaruh atau kontribusi sebesar 20,8 \% terhadap pertumbuhan ekonomi dan 79,2 \% dipengaruhi oleh faktor lain. Nilai t-statistik untuk variabel pengeluaran pemerintah sebesar 1,620 dan nilai probabilitity sebesar 0,136. Maka dapat disimpulkan bahwa variabel pengeluaran pemerintah berpengaruh tidak signifikan terhadap pertumbuhan ekonomi di kabupaten Bengkulu Selatan. 


\section{4) Kabupaten Bengkulu Utara}

Kabupaten Bengkulu Utara merupakan daerah yang memiliki hasil koefisien negatif dari persamaan yang terbentuk yaitu $\mathrm{Y}=7,541-1,401 \mathrm{x}$. Korelasi antara pengeluaran pemerintah dan pertumbuhan ekonomi juga lemah, hal tersebut ditunjukkan dengan nilai korelasi 0,275 dan nilai $\mathrm{R}^{2}$ sebesar 0,076 artinya pengeluaran pemerintah memberikan kontribusi hanya sebesar 7,6 \% terhadap pertumbuhan ekonomi dan 92,4 \% dipengaruhi oleh faktor lain. Nilai t-statistik untuk variabel pengeluaran pemerintah sebesar -0,905 dan nilai probabilitity sebesar 0,387. Maka dapat disimpulkan bahwa variabel pengeluaran pemerintah berpengaruh negatif terhadap pertumbuhan ekonomi. Kabupaten Bengkulu Utara juga merupakan salah satu kabupaten dengan rata-rata pertumbuhan ekonomi terendah yaitu $2,42 \%$ per tahun. Hal ini disebabkan oleh pertumbuhan ekonomi negatif yang terjadi pada tahun 2008 yaitu sebesar $-28,75 \%$.

\section{5) Kabupaten Kaur}

Pengeluaran pemerintah memiliki pengaruh positif terhadap pertumbuhan ekonomi di kabupaten Kaur. Dari hasil pengolahan data, persamaan regresi yang terbentuk adalah $\mathrm{Y}=$ $4,084+2,530 x$. Hubungan antara pengeluaran pemerintah dan pertumbuhan ekonomi juga lemah hal tersebut ditunjukkan dengan nilai korelasi sebesar 0,362. Sedangkan kontribusi pengeluaran pemerintah terhadap pertumbuhan ekonomi hanya $13,1 \%$. Nilai t-statistik untuk variabel pengeluaran pemerintah sebesar 1,099 dan nilai probabilitity sebesar 0,304. Maka dapat disimpulkan bahwa variabel pengeluaran pemerintah berpengaruh tidak signifikan terhadap pertumbuhan ekonomi di kabupaten Kaur.

\section{6) Kabupaten Seluma}

Dari hasil pengolahan data diketahui bahwa pengeluaran pemerintah memiliki pengaruh terhadap pertumbuhan ekonomi. Adapun persamaan regresi yang terbentuk adalah $\mathrm{Y}=$ $4,897+2,398 x$. Berdasar persamaan tersebut dapat dijelaskan bahwa koefisien regresi 2,398 dengan tanda positif. Hal ini menunjukkan bila semakin tinggi pengeluaran pemerintah akan dapat meningkatkan pertumbuhan ekonomi di kabupaten Seluma. Hubungan antara pengeluaran pemerintah dan pertumbuhan ekonomi cukup berarti, hal ini ditunjukkan dengan nilai korelasi sebesar 0,421. Kontribusi pengeluaran pemerintah terhadap pertumbuhan ekonomi hanya sebesar $17,8 \%$, hal ini ditunjukkan dengan nilai $\mathrm{R}^{2}$ sebesar 0,178. Nilai t-statistik untuk variabel pengeluaran pemerintah sebesar 1,315 dan nilai probabilitity sebesar 0,225. Maka dapat disimpulkan bahwa variabel pengeluaran pemerintah berpengaruh tidak signifikan terhadap pertumbuhan ekonomi di kabupaten Seluma.

\section{7) Kabupaten Mukomuko}

Pengeluaran pemerintah memiliki pengaruh positif terhadap pertumbuhan ekonomi. Dari hasil pengolahan data persamaan regresi yang terbentuk adalah $\mathrm{Y}=4,751+2,554 \mathrm{x}$. Hubungan antara pengeluaran pemerintah dan pertumbuhan ekonomi cukup berarti, hal tersebut ditunjukkan dengan nilai korelasi sebesar 0,454. Sedangkan kontribusi pengeluaran pemerintah terhadap pertumbuhan ekonomi hanya 20,6\%. Nilai t-statistik untuk variabel pengeluaran pemerintah sebesar 1,348 dan nilai probabilitity sebesar 0,220. Maka dapat disimpulkan bahwa variabel pengeluaran pemerintah berpengaruh tidak signifikan terhadap pertumbuhan ekonomi.

\section{8) Kabupaten Kepahiang}

Selama periode pengamatan, pengeluaran pemerintah berpengaruh tidak signifikan terhadap pertumbuhan ekonomi. Hal tersebut ditunjukkan dengan nilai t-statistik untuk variabel pengeluaran pemerintah sebesar 0,801 dan nilai probabilitity sebesar 0,453 . Persamaan regresi yang terbentuk adalah $Y=4,751+2,554 \mathrm{x}$. Hubungan antara pengeluaran pemerintah dan pertumbuhan ekonomi rendah/lemah, hal tersebut ditunjukkan dengan 
nilai korelasi sebesar 0,311. Sedangkan kontribusi pengeluaran pemerintah terhadap pertumbuhan ekonomi hanya 9,7 \% dan 90,3\% dipengaruhi faktor lain.

\section{9) Kabupaten Lebong}

Dari hasil pengolahan data diketahui bahwa pengeluaran pemerintah memiliki pengaruh terhadap pertumbuhan ekonomi kabupaten Lebong. Adapun persamaan regresi yang terbentuk adalah $Y=1,896+9,936 x$. Berdasar persamaan tersebut dapat dijelaskan bahwa koefisien regresi 9,936 dengan tanda positif. Hal ini menunjukkan bila semakin tinggi pengeluaran pemerintah akan dapat meningkatkan pertumbuhan ekonomi. Hubungan antara pengeluaran pemerintah dan pertumbuhan ekonomi kabupaten Lebong adalah kuat, hal ini ditunjukkan dengan nilai korelasi sebesar 0,709. Nilai $\mathrm{R}^{2}$ sebesar 0,503 artinya bahwa variabel pengeluaran pemerintah memiliki pengaruh atau kontribusi sebesar 50,3 \% terhadap pertumbuhan ekonomi dan 49,7 \% dipengaruhi oleh faktor lain. Nilai t-statistik untuk variabel pengeluaran pemerintah sebesar 2,011 dan nilai probabilitity sebesar 0,115. Maka dapat disimpulkan bahwa variabel pengeluaran pemerintah berpengaruh tidak signifikan terhadap pertumbuhan ekonomi.

\section{0)Kabupaten Bengkulu Tengah}

Pengeluaran pemerintah memiliki pengaruh positif terhadap pertumbuhan ekonomi. Dari hasil pengolahan data persamaan regresi yang terbentuk adalah $\mathrm{Y}=3,697+6,467 \mathrm{x}$. Hubungan antara pengeluaran pemerintah dan pertumbuhan ekonomi sangat kuat, hal tersebut ditunjukkan dengan nilai korelasi sebesar 0,943 dan kontribusi pengeluaran pemerintah terhadap pertumbuhan ekonomi sebesar $89 \%$ dan 11\% dipengaruhi oleh faktor lain. Nilai t-statistik untuk variabel pengeluaran pemerintah sebesar 4,018 dan nilai probabilitity sebesar 0,057. Maka dapat disimpulkan bahwa variabel pengeluaran pemerintah berpengaruh tidak signifikan terhadap pertumbuhan ekonomi.

\section{KESIMPULAN}

Simpulan yang dapat diambil dari penelitian ini adalah:

1) Pengeluaran pemerintah berpengaruh positif dan signifikan terhadap pertumbuhan ekonomi di provinsi Bengkulu. Jika pemerintah menaikkan pengeluaran pemerintah sebesar 1 miliar rupiah, maka akan dapat meningkatkan pertumbuhan ekonomi sebesar $1,17 \%$ per tahun.

2) Dari jumlah 10 kabupaten/kota di Provinsi Bengkulu, kabupaten Rejang Lebong dan kota Bengkulu yang memiliki hasil bahwa pengeluaran pemerintah berpengaruh positif dan signifikan terhadap pertumbuhan ekonomi di daerahnya. Kabupaten Bengkulu Utara memiliki pengaruh yang negatif sedangkan 7 kabupaten lainnya memiliki hasil yang positif namun tidak signifikan. Sebagian besar kabupaten di Provinsi Bengkulu dikategorikan sebagai daerah yang baru membangun yang merupakan hasil pemekaran pasca pemberlakuan otonomi daerah. Sehingga dalam jangka pendek pengeluaran pemerintah dianggap belum mampu menstimulus kegiatan sektor-sektor perekonomian serta memacu pertumbuhan ekonomi di daerah tersebut.

\section{SARAN}

Pengeluaran pembangunan atau belanja pelayanan publik lebih bersifat sebagai akumulasi stok kapital. Kondisi tersebut diharapkan dapat menjadi perhatian bagi pemerintah khususnya kabupaten pemekaran pasca pelaksanaan otonomi daerah untuk lebih meningkatkan alokasi pengeluaran pembangunan agar mampu menstimulus pertumbuhan ekonomi. 


\section{DAFTAR PUSTAKA}

Badan Pusat Statistik. (2001-2013). Provinsi Bengkulu Dalam Angka. Jakarta: BPS Jakarta Indonesia.

Badan Pusat Statistik. (2000-2004). Produk Domestik Regional Bruto Kabupaten/Kota Di Indonesia. Katalog BPS: 9205. Jakarta: BPS Jakarta Indonesia.

Badan Pusat Statistik. (2004-2009). Produk Domestik Regional Bruto Kabupaten/Kota Di Indonesia. Katalog BPS: 9302003. Jakarta: BPS Jakarta Indonesia.

Badan Pusat Statistik. (2003-3007). Statistik Keuangan Pemerintah Provinsi Bengkulu. Katalog BPS: 7414.17. Jakarta: BPS Jakarta Indonesia.

Badan Pusat Statistik. (2008-2012). Statistik Keuangan Pemerintah Provinsi Bengkulu. Katalog BPS: 7203002.17. Jakarta: BPS Jakarta Indonesia.

Dumairy. (1996). Perekonomian Indonesia. Jakarta: Erlangga.

Mangkoesoebroto, Guritno. (2001). Ekonomi Publik. Yogyakarta: BPFE.

Purba, Adearman. (2008). Analisis Faktor-Faktor Yang Mempengaruhi Pertumbuhan Ekonomi Di Kabupaten Simalungun. Diakses Tanggal 5 Juli 2014, https://www.USU Repository@2008.

Tambunan, Tulus. (2001). Perekonomian Indonesia: Teori dan Temuan Empiris. Jakarta: Ghalia Indonesia.

Todaro, M.P. dan S.C. Smith. (2006). Pembangunan Ekonomi Edisi ke Sembilan. Jakarta: Erlangga.

Wijono, Wiloejo, Wiryo. (2005). Mengungkap Sumber-Sumber Pertumbuhan Ekonomi Indonesia Dalam Lima Tahun Terakhir, Jurnal Manajemen dan Fiskal, Volume V, Nomor 2, Jakarta. 